\title{
LMPMI2014 国際会議報告
}

産業技術総合研究所 近藤余範

平成 26 年 9 月 2 日から 5 日にわたり，つくば国際会議 場（茨城県つくば市）にて 11th IMEKO Symposium LMPMI2014 (Laser Metrology for Precision Measurement and Inspection in Industry）が開催されまし た. 本会議は, 3 年ごとに開催される IMEKO TC14 主催 の国際会議で、レーザや光学を用いた計測技術に関する国 際会議です。

1 日目は，会議場にてウェルカムパーティーが行われま した。受付にて配られるプロシーディングは, なんとタブ レットです (図 1).タブレットの背景に描かれたノギス をもった女の子は, 本会議のオフィシャルキャラクター で, 実行委員長である高辻利之（産総研）様の娘さんがデ ザインされました。

2 日目と 3 日目は, 講演会が行われました. 4 件の基調 講演と 62 件の口頭発表（うちセッションキーノートスピ 一チ 5 件), 15 件のポスター発表がありました. 今回の会

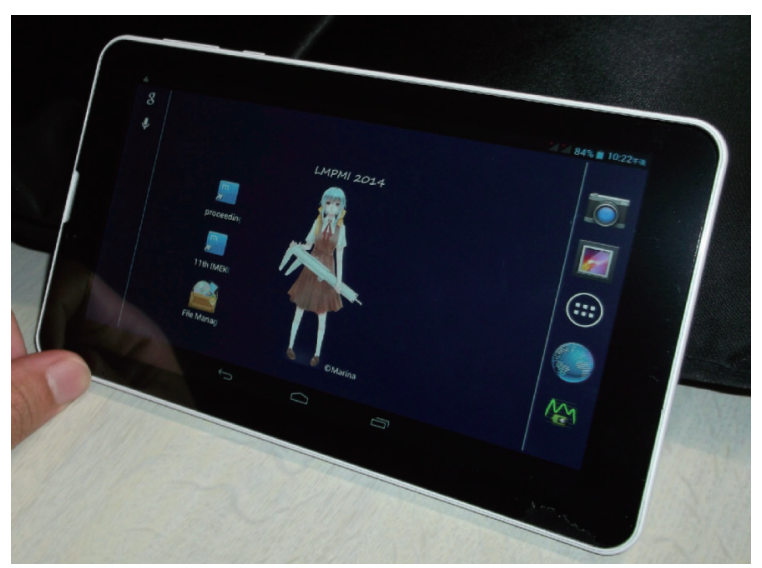

図 1 プロシーティングとして参加者に配布されたタブレット

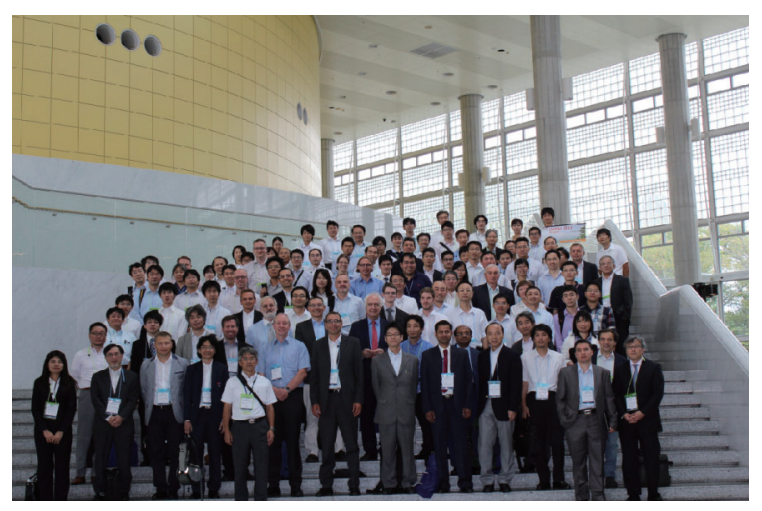

図 2 LMPMI2014 集合写真
議には, 13 の国から 119 名の研究者が参加され, 活発な 議論がなされました。図 2 は参加者による集合写真です. 参加者は, 日本, ドイツ, 中国, 台湾, ポーランド, イギ リスなどからお越しになりました（図3）.

会場内には，14 社の企業展示ブースが出展されました． 参加者には，7社以上のブースを回るとお土産がもらえる 「スタンプラリー」が配られました，始めのうちは，台紙 に記載された「STAMP Rally」の意味が, 海外の方には 理解されておりませんでした。筆者は, 台湾で開催された 国際学会 ASPEN2013で, 同様のスタンプラリーを経験し ておりました，スタンプラリーはアジア圈の文化なのでし ようか，いまだによく分かっておりません.「スタンプラ リー」が浸透すると, 多くの方々に企業ブースに足を運ん でいただけました。

2 日目の夜には, Young Researcher's meeting がアフィ リエイト委員会企画により実施され，若手研究者の交流も なされました。詳細は, 同号のアフィリエイト記事を参照 ください.

最終日は, (1)宇都宮コースと(2)東京コースの見学ツアー が開催されました。 (1)宇都宮コースは，株式会社ミットヨ 宇都宮工場を見学していただき, その後, 笠間焼の生産地 である笠間にて散策していただきました。(2)東京コース は, 東京スカイッリーから東京を一望していただき，その 後, 国立科学博物館や浅草を散策していただきました。

なお，次回の IMEKO は, XXI World Congress がプラ 八（チェコ共和国）にて 2015 年に開催されます。また, IMEKO TC14 主催国際会議は, ISMQCがフロリアノーポ リス（ブラジル）にて 2016 年に, LMPMIは開催地が未 定ですが 2017 年に開催されます。

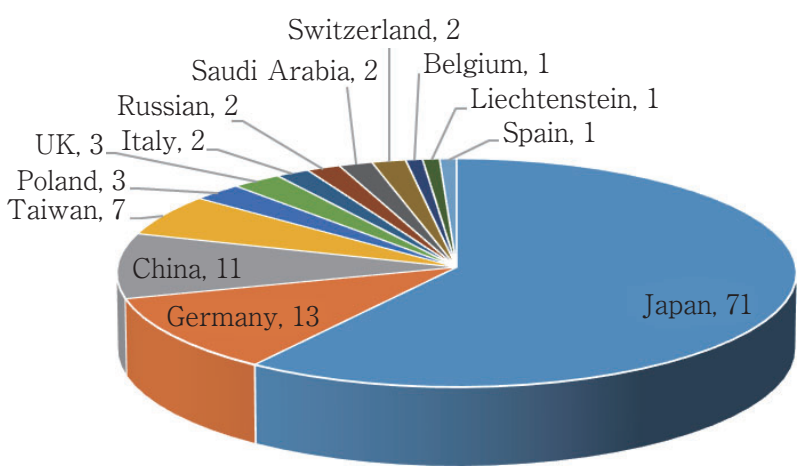

Sum of participants 119

図 3 参加者の国別内訳 